\title{
Rooftop Gardening: Making Roof Eye - Catching
}

\section{Swechha Poudel*}

Department of Environmental Science, Nepal

*Corresponding Author: Swechha Poudel, Department of Environmental Science, Nepal.

Received: November 05, 2019; Published: November 08, 2019

DOI: 10.31080/ASAG.2019.03.0717

"Making Worth Living Environment" I initiate this statement and allow me to visualize the surrounding we live in. The question arises, "How" to make it? In my view, rooftop garden is the best option for making environment attractive. The rooftops, balcony and terraces are the places that we can utilize for farming and making the surrounding more appealing.

Cities like Kathmandu are crowded with buildings, apartments and it is hard to plant a tree around houses. Going to the park or outside for fresh air is very tough in our busy schedule. As we all know, Plants and trees gives fresh air and makes our body and mind refresh. So, just think about of our own garden that gives amazing, beautiful garden with the full of beautiful flowers and handful of organic vegetables. Rooftop garden is the best place and could be a great idea.

The rooftop is the place where we can get good condition of light, air and water. Thus, we can plant on top of roof. Everyone in the family can spend some quality time in spending in own garden may divert and refresh our mind. Rooftop gardening is very easy to maintain, it is the best way to grow all types of natural sinks such as grassland, floral arrangement, green parks, or food crops on the rooftop of each and every building. These natural sinks help to absorb the dust and pollution of Kathmandu city which make Kathmandu city liable.

Rooftop farming allows for a completely natural form of farming. Flowers such as hibiscus, bougainvilleas, roses, Jasmine, marigold and Organic vegetables such as coriander, garlic, chili, onions, tomatoes and other seasonal vegetables can be grown on the roofs and balconies of houses. Rooftop organic farming can solve the issue of pesticides in vegetables as the products are free of chemicals.
We must give attention before turning the roof of the house into farmland, the roof and the condition of the roof must be inspected to see if it is technically waterproof and good for farming. As we all know, water scarcity could be a major challenge for rooftop farming, but rainwater harvesting is the way to counter this challenge.

These farmlands can be grown on the roofs and balconies of houses in clay pot, plastic container and other re-useable materials. Besides that, rooftop garden looks more attractive and beautiful by decorating clay pots and plastic containers. We can utilize and reuse of plastic bottles that makes sustainable gardening and make environment eco-friendly zone. There are numerous plastic containers that we use in our day to day life. Instead of throwing as a trash, we can use it effectively.

The environment is what matters and Rooftop Gardening does favor the protection of the environment. Let's root for Environment and Let's eat organic.

\section{Volume 3 Issue 12 December 2019 (C) All rights are reserved by Swechha Poudel.}

